\title{
The Use of Hemiepiphytes as Craft Fibres by
in the Colombian Amazon
}

\author{
María Paula Balcázar Vargas and Tinde van Andel
}

\begin{abstract}
Aerial roots of hemiepiphytes are used throughout the Amazon Basin for house construction, basketry, traps and furniture. Here we describe how 15 species of hemiepiphytes are extracted by six indigenous groups in the Colombian Amazon for traditional artefacts, commercial crafts and as raw material for the furniture industry. Indigenous classification systems, use preferences, and the influence of the craft trade on indigenous livelihoods are discussed. The craft trade seems to improve the living conditions of local communities by making them less dependent from local guerrilla and coca production. However, we seriously question the sustainability of current fibre extraction. Designing adequate management plans for commercial hemiepiphytes is essential to guarantee the future supply of these valuable non-timber forest products.
\end{abstract}

\section{Introduction}

The harvest and trade in non-timber forest products (NTFPs) contribute greatly to rural livelihoods worldwide, and their harvest seems much less environmentally destructive than timber extraction, cash crop agriculture or cattle ranching. This has led to the assumption that increased commercialisation of NTFPs could promote both economic development and forest conservation (Nepstad \& Schwartzman 1992, Plotkin \& Famolare 1992). Recently, the high expectations that NTFPs could safeguard tropical rain forests have been somewhat tempered (Ruiz-Perez \& Arnold 1996, Shanley et al. 2002a, Ticktin 2004). Low species abundance in highly diverse rain forests means a low availability of the extracted product per hectare, which may result in overexploitation if there is a strong market demand (Boot 1997, Clark \& Sunderland 2004, Hall \& Bawa 1993, Peters 1996). Many attempts to commercialise NTFPs have failed because of a lack of well-developed markets (Clay 1992, Newton et al. 2002, Shanley et al. 2002b). The possibilities for remote forest-dwellers to earn a living with NTFPs are quite limited, as it may take days to travel to a market place. High transport costs make it hard to compete with the same products harvested closer to urban settlements (Shanley et al. 2002a, van Andel 2000). For isolated indigenous communities, wildlife is often the only product worthwhile marketing, since its unit price is high and wild animals around urban settlements have become rare (Davies 2002, van Andel et al. 2003).

There seem to be exceptions to this phenomenon. The harvest of aerial roots of hemiepiphytes for the manufacture of wicker furniture and basketry is a promising business in the Amazon Basin (Baluarte \& del Castillo 2001, Hall 2000, Hoffman 1997, Plowden et al. 2003, Whitehead \& Godoy 1991). Hemiepiphytes are relatively abundant and their aerial roots can easily be pulled down. The mother plant generally withstands the harvest: it stays connected in the canopy and produces new roots (Plowden et al. 2003, Putz \& Holbrook 1986). International demand for wicker furniture is increasing (Baluarte \& del Castillo 2001, Plowden et al. 2003, Whitehead \& Godoy 1991). The roots can be harvested year-round and

\section{Correspondence}

María Paula Balcázar Vargas, Prins Berhardlaan 11, 1111EP Diemen, THE NETHERLANDS.

mpbalcazar@yahoo.com

Ethnobotany Research \& Applications 3:243-260(2005) 
require extensive manual labour in their conversion into the final product. When the price for raw material is high enough, people often protect trees heavily colonised by hemiepiphytes. They prefer harvesting aerial roots for the following years above earning once by selling its timber. This example shows the potential of harvesting NTFPs as a means of forest conservation (Hofmann 1997, van Andel 2000).

In contrast to true epiphytes, which spend their entire lives on tree branches without touching the soil, hemiepiphytes maintain soil contact for at least part of their life by means of aerial roots. Primary hemiepiphytes start their life as epiphytes, germinating on a host tree and sending down aerial roots to the ground to take up nutrients (Benzing 1990, Putz \& Holbrook 1986). Some primary hemiepiphytes may strangle or kill their host (e.g., Clusia spp., Ficus spp.); others never do so (Philodendron spp.). Secondary hemiepiphytes germinate on the forest floor before climbing a host tree, keeping their roots connected to the soil during their entire life cycle (Kress 1986, Moffett 2000). In the Neotropics, this type is represented by several genera in the families Araceae and Cyclanthaceae. Some primary and secondary hemiepiphytes produce strong, pliable aerial roots, used since ancestral times by indigenous people as lashing material in construction and handicrafts (Bennett 1992, Gentry 1992, Knap-Vispo et al. 2003, Roth 1924). The furniture workshops that have emerged throughout the Amazon Basin predominantly use the roots of Heteropsis flexuosa (H.B.K.) G.S. Bunting (Araceae) and Clusia spp. (Clusiaceae) as raw material (Hoffman 1997, van Andel 2000, Wallace \& Ferreira 2000).

Colombia is one of the most species-rich areas for Araceae, and the Western Amazon harbours the greatest diversity of Heteropsis species (Croat 1992). Detailed studies were carried out on hemiepiphytic Araceae in Ecuador (Leimbeck \& Balslev 2001) and on Heteropsis in Venezuela (Knab-Vispo et al. 2003), Guyana (Hall 2000, Hoffman 1997) and Brazil (Plowden et al. 2003, Wallace \& Ferreira 2000). Little is known, however, about the abundance and diversity of these plants in the Colombian Amazon. Even the most recent vegetation studies in that area (Duque 2004, Villegas et al. 2004) did not include hemiepiphytes their botanical inventories.

Ethnobotanical research in the Colombian Amazon has focused on medicinal plants (Schultes \& Raffauf 1990), palms (Bernal 1992) and woody plants (Acero 1979, Garzón \& Macuritofe 1992, Glenboski 1983, La Rotta 1982, La Rotta et al. 1987). Studies on indigenous crafts and culture report only few hemiepiphytes, but scientific names are often lacking or incorrect (González 1989, Ortiz 1994, Reichel 1987). With the exception of Cárdenas \& López (2000), even the most recent studies on NTFPs in the Colombian Amazon (Duivenvoorden et al. 2001, Sánchez 2005) have paid little attention to the use of aerial roots for craft making. This is understandable, because of the difficulties in gaining access to the canopy and collecting the specimens (Moffet 2000). This means, however, that a group of plants that plays a major role in the livelihoods of indigenous peoples has remained neglected.

For several decades, the indigenous population of Colombia has faced growing economic and cultural pressure, putting the retention of their traditional knowledge of plant use in peril (Rodríguez 2003, Sánchez 2005). Due to substantial changes in settlement patterns and greater integration in the market economy, traditional relations with nature have transformed and pressure on natural resources has increased (van der Hammen 2003). The ongoing turmoil in violence and civil warfare has paralysed large segments of the political, economic and social system in Colombia (United Nations Office on Drugs and Crime, www.unodc.org). In fact, the guerrillas of the Colombian Revolutionary Armed Forces (FARC) control large parts of the Colombian Amazon. Although the national army recently recovered part of the Caquetá department (Angrist \& Kugler 2004), the region remains a "department of concern" by the UNHCR (www.reliefweb.int). The trade and cultivation of coca (Erythroxylum coca Lam.) is a major source of rural income in the Colombian Amazon (Angrist \& Kugler 2005, Villalón 2005). Alternative economic development programs have produced few tangible results so far (Paredes et al. 2003).

Here we present the results of ethnobotanical fieldwork by the first author from 1998 to 2001 among six indigenous groups in the Colombian Amazon. We try to provide answers to the following questions: Which species of hemiepiphytes are collected for craft making? What is the importance of these plants in the subsistence economy of local communities? Does the trade in these NTFPs contribute to improved livelihoods, sustainable forest management and the preservation of indigenous culture? Our results show that, with a sophisticated marketing of indigenous crafts, aerial root extraction could offer indigenous communities a viable economic alternative to illegal coca production and more independence from guerrilla activities. To prevent depletion of this valuable resource, however, root harvesting should be ecologically sustainable.

\section{Study Sites}

Fieldwork took place in three different sites within the Colombian Amazon: the middle Caquetá River, Amacayacu National Natural Park and the Brazo Amanavén (Figure 1). The middle Caquetá River is situated in the lowlands of the Colombian Amazon, between Araracuara and the Metá Creek, Department of Amazonas ( $0^{\circ} 30^{\prime}-1^{\circ} 00^{\prime} \mathrm{S}$ and $72^{\circ} 30^{\prime}-71^{\circ} 30^{\prime} \mathrm{W}$ ). Altitude is about $180 \mathrm{~m}$ above sea level; the mean annual temperature ca. $26^{\circ} \mathrm{C}$. Annual rainfall averages 3060 mm (Duivenvoorden \& Lips 1993). The vegetation is characterised by species-rich humid tropical for- 


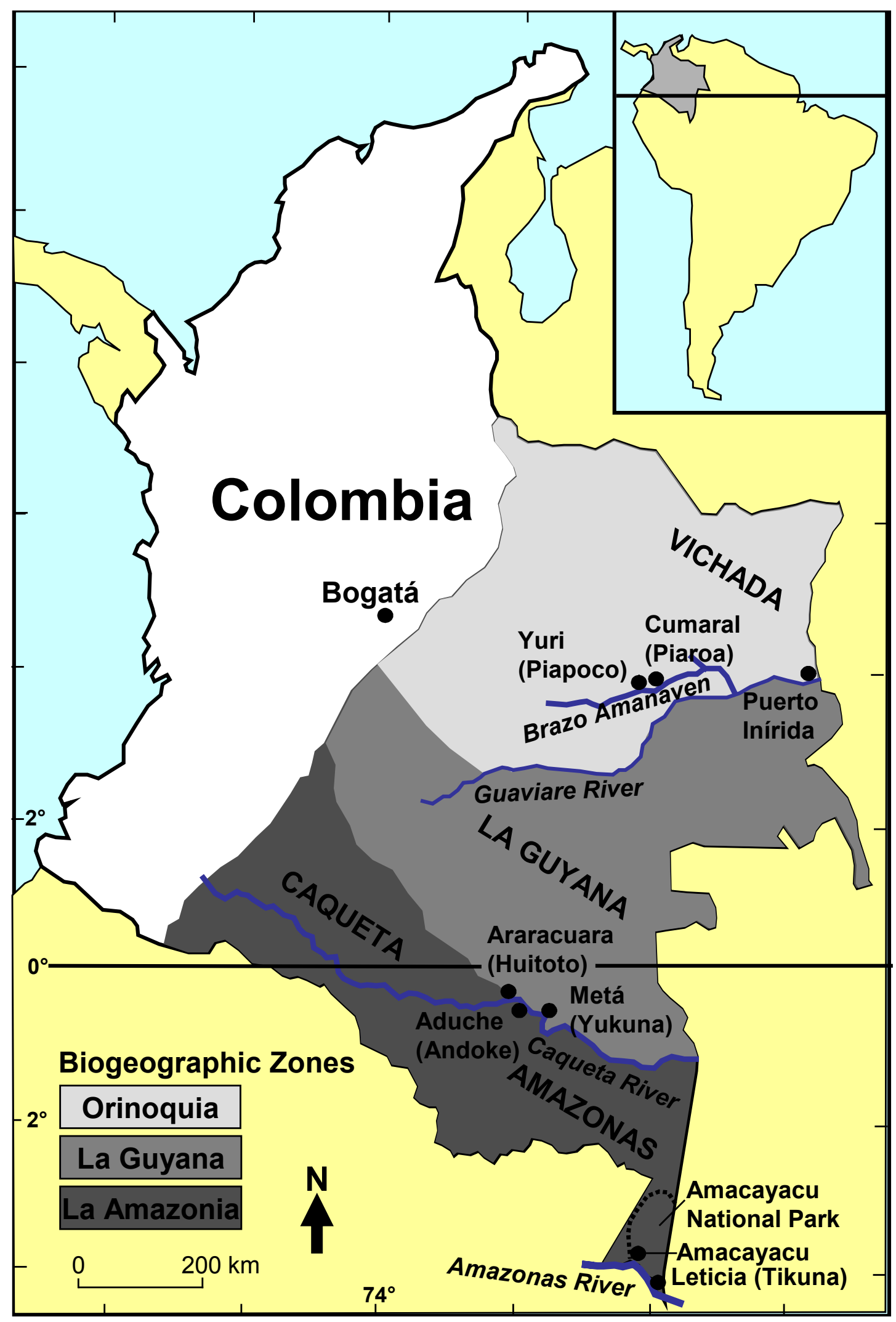

Figure 1. Colombia with three biogeographic zones and study site locations. 
est, with permanently inundated swamps, floodplain forest and tierra firme forests (Duque et al. 2002). Various indigenous tribes inhabit the region: Huitoto, Muinane, Andoque, Nonuya-Bora, Miraña and some isolated members of the Yukuna-Matapi (DNP 2002, Sánchez 1997). Population density in this region is less than 0.2 people per $\mathrm{km}^{2}$ (Duivenvoorden \& Lips 1993). More than $75 \%$ of the Amazon Department area has been declared Amerindian resguardos, mostly falling within the sizeable Predio Putumayo (ca. 5 million ha), which gives them collective ownership of this territory (van der Hammen 2003). The environmental policy of the Colombian government for the Amazon Basin tries to combine conservation with development, looking for improvement of living conditions for the human population within an ecologically viable framework (DNP 1991).

Research was carried out in the Andoke community of Aduche (232 persons), the Huitoto and Yukuna-Matapí communities living around Araracuara and with one Yukuna-Matapí family along the Meta Creek (Figure 1). All indigenous tribes practise subsistence agriculture, while some of those living near Araracuara are involved in commercial catfish harvesting (Rodriguez 1999). There were no recent missionary activities in the area. In 1999, the FARC invaded the entire middle Caquetá region and research facilities were abandoned. In 2003, the Colombian army took over the area again and civil flights to Araracuara were resumed (El Tiempo 2003, Angrist \& Kugler 2004).

The second part of the research took place in the Tikuna communities of San Martín, Mocagua, El Vergel, and Macedonia, surrounding the Amacayacu National Park, located in the far south of the Amazonas Department (Figure 1). Altitude is about $84 \mathrm{~m}$ above sea level, the mean annual temperature $26^{\circ} \mathrm{C}$ and annual rainfall averages $3100 \mathrm{~mm}$ (IGAC 1970). The community of San Martín (pop. 420) is located in the park itself and belongs to the Puerto Nariño resguardo (pop. 3362, 86.872 ha), while Mocagua (pop. 183, 5255 ha), El Vergel (pop. 56, 2525 ha) and Macedonia (pop. 414, 3410 ha) are situated in the buffer zone of the park, on the bank of the Amazon River (DNP 2002). The Amacayacu communities have been in contact with the catholic missions for a long time, but recently an evangelistic group has gained considerable influence in the Macedonia community.

The region's major landscape units are floodplains, tierra firme forest and permanently waterlogged swamps (Villegas et al. 2004). Because of the strategic position of Leticia on the Amazon River and bordering Peru and Brazil, the Colombian army has a strong foothold in the area and maintains a strict control over illicit coca cultivation. Small-scale tourism is present in the area: several community members sell craftwork and work as tourist guides. NTFP harvesting is forbidden in National Parks, but since some resguardos overlap with the protected area, hunting, fishing, and collecting NTFPs is allowed for the time being (van der Hammen 2003). The research in Amacayacu and Araracuara took place in the framework of the Tropenbos-Colombia programme.

The Brazo Amanavén, a branch of the Guaviare River, is located in the Selva del Matavén (Vichada Department), between $4^{\circ} 30^{\prime} \mathrm{N}$ en $68^{\circ} 20^{\prime} \mathrm{W}$ (Figure 1). Altitude is about $100 \mathrm{~m}$ above sea level, the mean annual temperature is ca. $25^{\circ} \mathrm{C}$. Annual rainfall (in Puerto Inírida) is $2982 \mathrm{~mm}$ (http://bart.ideam.gov.co/cliciu/inirida/temperatura.htm). Six indigenous tribes live here: the Sikuani, Piapoco, Puinave, Piaroa, Curripaco and Cubeo. Research took place in the Piaroa community of Cumaral $\left(234 \mathrm{~km}^{2}\right.$, pop. 112) and in the Piapoco community of Yuri (158 km², pop. 62). Population density in the local resguardos averages 0.9 persons per $\mathrm{km}^{2}$ (DNP 1999). Since the 1940s, the protestant New Tribes Mission (led at time by the legendary German missionary Sofia Müller) has been active in the Brazo Amanavén. The Piaroa in particular are still heavily involved in this religion. Converted Piaroas often have more decision-making power than village captains and sometimes replace them as community representatives. They often perceive outsiders as messengers from the devil (Herrera \& Lobo-Guerrero 1998).

The vegetation of the Selva de Matavén can be described as the ecotone zone between the Amazonian forest and the Orinoco savannah, with seasonally inundated tropical forest, many small lakes and swamps (www.etnollano.org). Although the annual rate of natural ecosystem loss in the region Inírida-Matavén was estimated at only 0.4\% (Romero et al. 2004), many illegal coca fields have been established in the last decade (Lobo-Guerrero et al. 2000). Fieldwork took place in the framework of the Colombian NGO Etnollano, which aims to improve the livelihood of the Vichada communities by supporting their cultural heritage, sustainable development and conservation of their surrounding biodiversity (www.etnollano.org).

\section{Methodology}

Fieldwork took place between May and December 1998 (Caquetá), from October to December 1999 (Brazo Amanavén), and from June to September 2001 (Amacayacu). Interviews were held in Spanish or in Piaroa and Piapoco (by means of a translator) with male community elders specialised in craft making and hemiepiphyte collection. Through participant observation we documented different aspects of craft production, such as traditional methods of species identification, aerial root harvesting, storage and weaving techniques. The occurrence of hemiepiphytes was inventoried in different vegetation types. Vouchers of hemiepiphytes were collected using standard botanical collection methods. Duplicates were deposited and identified at the National Herbarium of Colombia (COL) and the Instituto Amazónico de Inves- 


\section{Balcázar and van Andel - The Use of Hemiepiphytes as Craft Fibres by Indigenous Communities in the Colombian Amazon}

tigaciones Científicas SINCHI (COAH). Some harvesting experiments were carried out along the Meta Creek (Caquetá), in which either $100 \%, 70 \%$ or $50 \%$ of all roots of $H$. flexuosa were removed. Unfortunately, it was not possible to return to the study site, as the FARC guerilla occupied the region six months later.

\section{Results and Discussion}

\section{Indigenous classification and use preference}

Fifteen useful hemiepiphytic species (of which 10 could be identified to species level) were found in the three study sites (see Appendix 1). The majority belonged to the Araceae family (11 species), followed by Cyclanthaceae (4 spp.). The species listed in Appendix 1 produce aerial roots applied in baskets, fish and mammal traps, brooms, and as lashing material for house frames, walls, thatched roofs and fences (see Figure 2 for some examples).

The local Spanish name for aerial roots is bejucos, which means 'liana'. None of the indigenous groups made a distinction between primary and secondary hemiepiphytes, but the elderly men specialized in craft making clearly distinguished different 'species'. They often did not recognize the hemiepiphytes by their leaves (since plants were often located high up in the canopy), but always knew them by their aerial roots. Texture and colour of the root cortex and inner stele, the presence or absence of latex, root quality, diameter and resistance were characteristic to each 'species'. The indigenous species division did not entirely match the distinction in our taxonomic groups.

Heteropsis flexuosa and Philodendron solimoesense A.C. $\mathrm{Sm}$. were the only species used by all six indigenous communities. $H$. flexuosa seemed to be the most abundant of all craft fibres encountered in this study. The superior quality, easy processing and durability of the roots in both water and open air permits the creation of a wide range of cultural artefacts, varying from animal and fish traps to binding material for community roundhouses (malocas). Other Heteropsis species produce roots of lesser quality. Baskets from Heteropsis spruceana Schott var. spruceana are only used for carrying light weights, because the roots are thin and frail. The typical flat roots of Heteropsis linearis A.C. Sm. are of good quality, but the plant is rare and thus rarely used. Although their vegetative characteristics were almost the same, local informants made a distinction between Heteropsis sp. MPB648 and $H$. flexuosa, because the exodermis colour of the former was either white or pale brown, while that of the latter was grey. Unfortunately, no fertile individuals of Heteropsis sp. MPB648 were located. Although leaf and flower characteristics are clearly different, the Huitoto refer to Heteropsis sp. MPB648 and Heteropsis oblongifolia Kunth by the same vernacular name (kirio), because the colour of the exodermis is similar. For the same reason, the Piapoco and Piaroa do not distinguish between Heteropsis sp. MPB648 and Heteropsis spruceana Schott var. robusta Bunting. The Spanish term used for the entire genus Heteropsis is yare in the Caquetá, mimbre in the Brazo Amanaven and the Peruvian term tamishi in the Amacayacu area. The latter term also includes Thoracocarpus bissectus (Vell.) Harling. Appendix 1 clearly shows that extractors only make the distinction between different aerial root types in their indigenous language.

For basketry, species of the family Cyclanthaceae are preferred, such as T. bissectus, Evodianthus funifer (Poit.) Lindm., Sphaeradenia sp. MPB676 (only among the Andoke) and Asplundia sp. MPB1405 (Tikuna only). Due to their resistance and durability, people use Cyclanthaceae baskets to transport heavy loads of agricultural produce to the village. Some baskets can hold over $90 \mathrm{~kg}$ of cassava roots. The five Philodendron species listed in Appendix 1 are widely used as binding material for house and maloca frames. $P$. solimoesense has orange exudate, thick roots and thorn-like structures on the root cortex. Typically, the plant is used for basketry only in the Vichada. P. solimoesense did occur in the other study sites, but because of the irritating root exudate, people harvested them only occasionally to fasten house frames. Botanical illustrations, detailed weaving techniques and photographs of crafts in different stages of manufacture were published by Balcázar \& Sastoque (1999) and Balcázar (2000, 2002). These booklets were distributed as education material among schools in the Araracuara and Amacayacu region.

\section{Species distribution}

Most useful hemiepiphytes were restricted to nonflooded tierra firme forest, such as $H$. spruceana var. spruceana, Philodendron sp. MPB1401, Philodendron sp. MPB1423, Philodendron goeldii G.M. Barroso, Asplundia sp. MPB1405, E. funifer and Sphaeradenia sp. MPB676. Species like $H$. flexuosa, Heteropsis sp. MPB648 and $H$. spruceana var. robusta occurred occasionally in swamp forest, but had a higher abundance in tierra firme forests. On the contrary, $P$. solimoesense did occur in tierra firme, but was more common in swamp forest. Thoracocarpus bissectus occurs in all vegetation types except for the waterlogged swamps. The species had a very low abundance in the Brazo Amanavén region. H. linearis was only rarely found in tierra firme in the Caquetá and Amacayacu region.

\section{Harvesting techniques}

Harvesting techniques were more or less the same for all six ethnics groups. Some elder women knew how to pull down aerial roots, but it was almost exclusively a male activity. When people needed a particular species for artefact production, they organised a collection trip or it simply harvested the roots during hunting or fishing activities. Most Heteropsis and Cyclanthaceae roots wrap around 


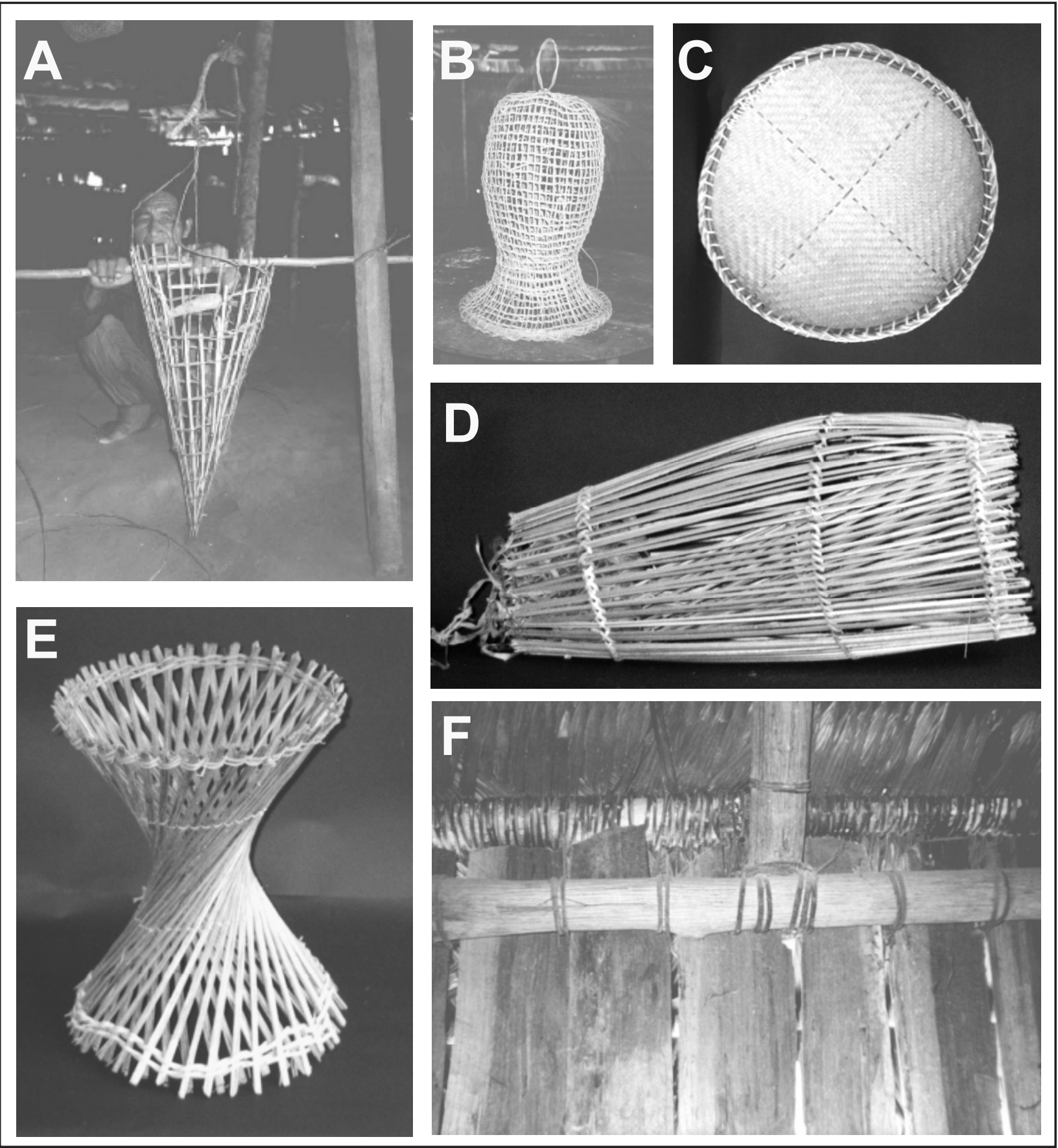

Figure 2. A) Huitoto fish trap (te'ki); B) Huitoto fyke or 'female' creel (rigoru); C) Yukuna balay (jirú); D) Andoke 'sardine' fyke (yióo); E) Yukuna pot support or magic charm cup (umichiripuku) or Piaroa sämurucä; F) Binding material for houses.

the trunk of their host trees or contain many knots, making them unsuitable for weaving. The roots preferred for craft production are the ones that drop straight from the branches of the tree to the ground. Harvesters looked closely at the roots and chose those that were mature (in contact with the soil absorbing water and nutrients) and had the required pliability, thickness and length. Good quality roots contain few nodes and show no signs of weevil infestation. When the desired roots were found, they were cut at ground level with a machete, separated from the other entangling roots and carefully pulled down to avoid damage to the 'mother plant'. Roots of $P$. goeldii, $P$. solimoesense, Philodendron sp. MPB 1401 and T. bissectus are quite sturdy, making it necessary to climb up the 


\section{Balcázar and van Andel - The Use of Hemiepiphytes as Craft Fibres by Indigenous Communities in the Colombian Amazon}

tree and cut them at the base of the mother plant. Since this required much work, people occasionally felled heavily colonised trees in order to obtain the roots.

Once pulled down, harvesters coiled the roots up in bundles and took them back to the village, where they left them to dry for several days, in the shade or sun, with or without cortex, depending on the species. Roots were soaked in water for two or three days to regain their pliability before stripping and weaving. In the past, indigenous crafts makers did not store the roots for a long time. They gave away leftover roots to neighbours or friends. Since the onset of commercial fibre harvesting in the Vichada, the roots may be stored for several months before they are used for crafts or sold to 'floating shopkeepers', who ship them to Puerto Inirida where they are either processed or flown to Bogotá.

Depending on the species and the desired artefact, roots undergo different treatments. They are cut just above and just after each node to obtain a straight piece of smooth fibre that is easy to process. The cortex of most Heteropsis species can be peeled off with the fingers, but the cortex of Philodendron and Cyclanthaceae roots must be scraped off with a knife, which is rather time-consuming. In the case of $P$. solimoesense, this is done carefully, because of the irritating exudate. After peeling, root are split lengthways into long, flat ribbons. The inner cores are polished with a knife in order to remove the cutting edges and thereby prevent injuries during the manufacturing process. Roots used as tying material for house frames or animal traps are used with their cortex.

When roots were only used for subsistence activities, extractors generally removed only two or three mature roots per plant, even if more suitable roots were present. They said that extracting too many roots would slow down growth. For commercial basketry, much larger quantities were needed and indigenous management systems were abandoned. Almost all mature roots were cut and only a few immature roots were left. According to the extractors, this had a weakening effect on the mother plant. This is supported by the results of harvesting experiments in the Caquetá region. After cutting $100 \%$ of the (mature and immature) roots of several $\mathrm{H}$. flexuosa individuals, they all died within two weeks. Cutting $70 \%$ of the marketable roots caused the plants to wilt and drop their inflorescences. Harvesting only $50 \%$ of the mature roots did not seem to affect the plants at first sight. Unfortunately, these experiments were not continued as the Caquetá River was occupied by the FARC guerilla shortly after the first fieldwork period. In the Vichada, however, the increased extraction caused by the craft trade seems to have led to a sharp decrease in the population of hemiepiphytes and available roots near the Piapoco and Piaroa communities.

\section{Loss of material culture}

Just like the harvesting of roots, the weaving of baskets and setting of animal traps is a typical male activity in the Colombian Amazon. Until recently, indigenous men learned how to make baskets when they were ready to get married (at the age of 20). At the time of this study, youngsters in all six communities seemed less interested in learning to make their traditional artefacts. This trend was most prevalent in the Tikuna communities in Amacayacu, where basketry had become rare and people depended on plastic commodities from Leticia. The Caquetá and Brazo Amanavén communities were more isolated from the market economy, but while every household in the Caquetá seemed to produce their own artefacts, in the Brazo Amanavén these were only present in the household of elder people. The loss of material culture in the Vichada was probably related to evangelism activities in the past.

Basketry used in the preparation of cassava bread and flour, the staple food of most Amazon Indians, was present in all Caquetá households and in dwellings of elder people in the Brazo Amanavén. These objects were less common in Tikuna households and younger Piapoco and Piaroa households. Artefacts traditionally used for hunting and fishing, such as fish traps (Figure 2), had largely been replaced by guns, metal harpoons and hooks, except for the Caquetá region, where they were made occasionally when money ran short.

Some basket types have disappeared almost entirely, such as the salt cup, used in the past to extract salt from the palm Astrocaryum gynacanthum Mart. (Sánchez 2005). People now buy salt at nearby shops and markets. Other artefacts changed their function: the sämurucä (Figure $2 \mathrm{E})$, previously used to support hot ceramic pots, is nowadays used as a chicken pen.

Some traditions have been lost completely. In the early days, the Piaroa wrapped their dead in a yuruhuäbä, a 'package' made of palm leaves fastened with aerial roots, and left them between rock caverns. Today, they bury their deceased in a cemetery.

While the Caquetá and Amacayacu indigenous groups all carried their crops or forest products in circular baskets (Figure 3), some Piapoco and Piaroa families still used their traditional catumare, a backpack-like basket with a wooden frame. Originally made of palm leaves, the catumare is currently woven from Heteropsis sp. MPB 648 or $H$. spruceana var. robusta. Other tribes taught the Piapoco and Piaroa that aerial roots were more durable and allowed them to carry heavier loads. The six groups share only one type of basket: the so-called canasta ojon, which is found among many indigenous tribes in the world (Figure 3E). 


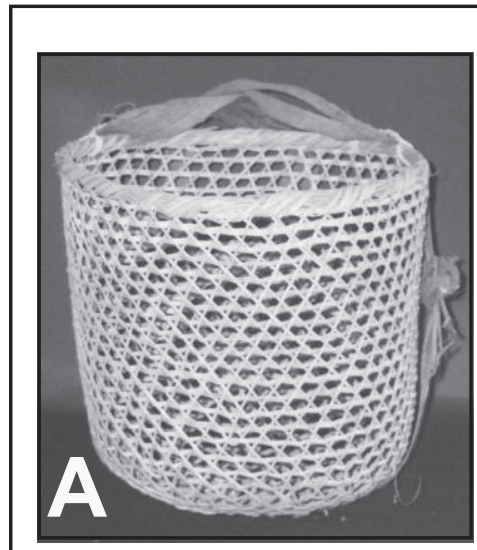

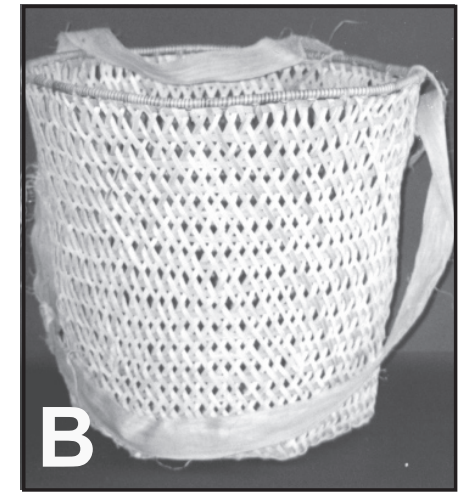

Figure 3. Various basket types: A) Andoke luxury basket (inihonnde'o); B) Yukuna basket (pajluaja ñe'ejeri or canasta de una correa); C) Yukuna basket (iyamá ñe'ejeri or canasta de dos correas); D) Huitoto basket (i’bigai); E) Canasta ojon.
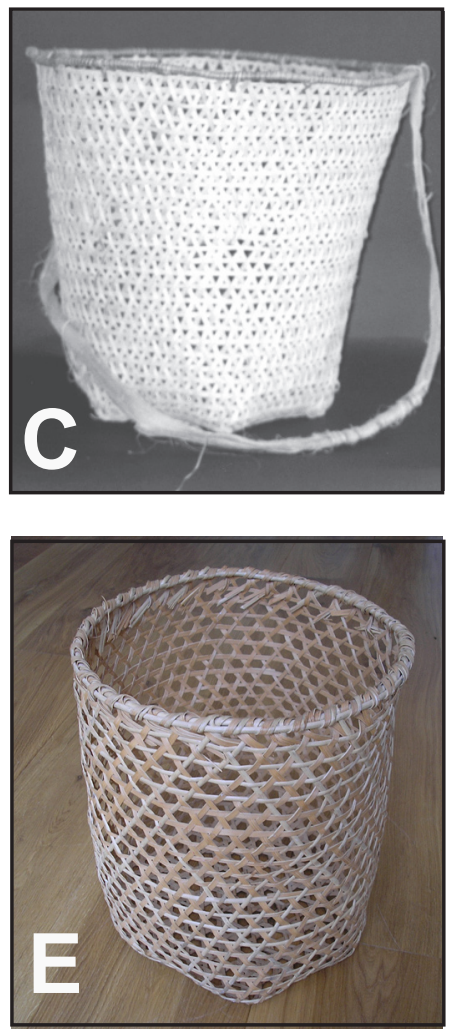
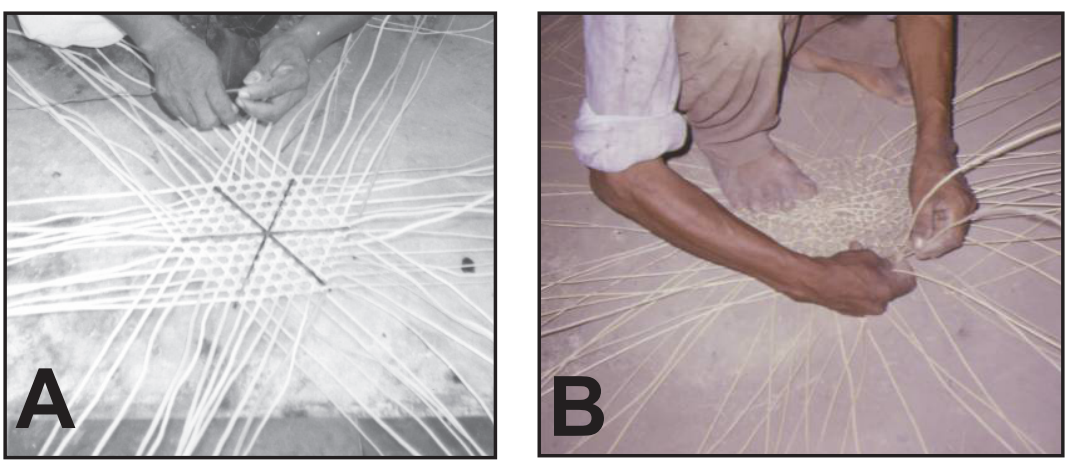

Figure 4. Different bottom weaving techniques: A) Yukuna basket; B) and C) Andoke luxury baskets; D) Huitoto basket. Drawing by Abel Rodriguez, Caquetá.
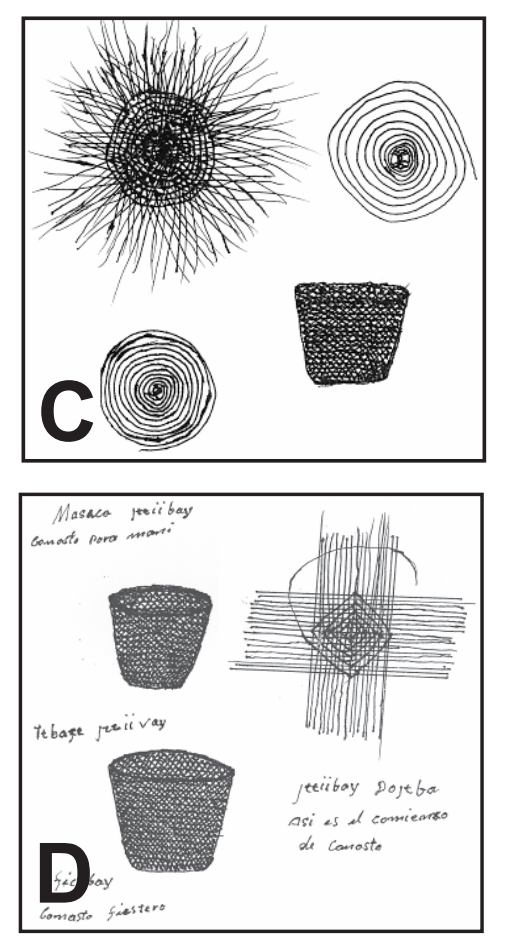


\section{Balcázar and van Andel - The Use of Hemiepiphytes as Craft Fibres by Indigenous Communities in the Colombian Amazon}

The Caquetá tribes still used various species as lashing material in housing construction, but most roofs in the Vichada and Amacayacu had zinc sheets provided by government-supported development projects. Although the Caquetá and Vichada tribes have had ample time to exchange weaving techniques, each ethnic group still made baskets characteristic to their tribe (Figures 2, 3 \& 4). The main differences between Caquetá baskets are found in the base and rim (Figure 4).

\section{Trade in raw material and handicrafts}

The four Tikuna communities sold their crafts at the Leticia market and to tourists visiting the Amacayacu National Park. In addition to baskets, they made woodcarvings (of Brosimum spp.), Ficus bark cloth and hammocks of Astrocaryum chambira Burret fibre. The Camara de Comercio de Amazonas promotes Amacayacu crafts on the Internet (www.ccamazonas.org.co). No trade in aerial roots or handicrafts existed in the middle Caquetá River in 1999. Although this remote area is only accessible by airplane or river, commercial fishing is the primary source of income for most non-indigenous inhabitants. Large quantities of frozen catfish are transported by cargo plane to Bogotá (Rodriguez 1999). The Caquetá has never been a tourist destination.

At the time of this research, the Piapoco were not marketing their crafts, but they did sell substantial volumes of unprocessed roots to floating shopkeepers. These traders travelled frequently along the Brazo Amanavén to exchange luxury goods (sugar, batteries, gasoline, clothes, etc) for agricultural products, bush meat, fish and other non-timber forest products. They transported the fibres to furniture workshops in Puerto Inírida. Furniture prducers preferred the white roots of Heteropsis sp. MPB648 and $H$. spruceana var. robusta above the grey roots of $H$. flexuosa.

The Piaroa village of Cumaral was the only community truly dedicated to the craft trade. In the late 1980s and early 1990s, Cumaral villagers regularly sold unprocessed roots and earned additional income as wage labourers at illegal coca plantations (Lobo-Guerrero et al. 2000). Since 1993, Fundación Etnollano has tried to combine the recovery of indigenous knowledge with generating alternative sources of income by marketing the Piaroa crafts. Transport to the nearest market (Puerto Inírida) is expensive and infrequent, and because of its remoteness and the heavy guerilla presence, there is no tourism in the Vichada. Stimulating the craft trade would seem a foolish idea with such high transport costs and the absence of a market for elaborated indigenous craftwork. Etnollano, however, found a solution to these problems with a sophisticated way of marketing. They buy the crafts in the communities, transport them to the Puerto Inírida, fly them to Bogotá and sell them in their office and at the annual Expoartesanias fair, organised by Artesanías de Colom- bia, a governmental institution that helps to sell artefacts from rural communities all over the country (www.artesaniasdecolombia.com.co). The FARC guerillas apparently do not interfere with the craft transport.

At first, Etnollano tried to market the traditional Piaroa basketry, but sales were low. They decided to hire a craft designer who taught the villagers new designs and weaving techniques. Today, Piaroa men and women of all ages produce crafts of excellent quality. Etnollano buys the crafts for a reasonable price, based on the man hours spent on searching, harvesting and processing the material and weaving the crafts. Being a non-profit NGO, much of the revenue returns to the Piaroa communities. The salary of the craftsmen is similar to that of a wage labourer on a coca field.

\section{Hemiepiphytic diversity and uses in other parts of Amazonia}

Our inventory revealed more species of useful hemiepiphytes than other studies in Colombia (Cárdenas \& Lopez 2000, Sánchez 2005), Ecuador (Bennett 1992, Paz y Miño et al. 1995), Peru (Baluarte \& del Castillo 2001), Venezuela (Knap-Vispo et al. 2003), Guyana (Hoffman 1997, van Andel 2000) and Brazil (Plowden et al. 2003, Whitehead \& Godoy 1991). Although certainly more species of Heteropsis occur in Brazil than in Colombia (Mayo et al. 1997), their indigenous uses were never recorded in detail. The same accounts for the other countries. Most studies on furniture production focus on Heteropsis flexuosa and its extraction in tierra firme forest (Hall 2000, Hoffman 1997, Plowden et al. 2003, Wallace \& Ferreira 2000). Our results show that other economically valuable species (e.g., Heteropsis sp. MPB648, H. spruceana var. robusta and T. bissectus) also occur in swamp forest. Whilst in Guyana T. bissectus is not commercially extracted because of its sturdy roots and skin, it is the preferred species for basketry in the Colombian Amazon (this study) and Peru (Baluarte \& del Castillo 2001).

Although the Tikuna made less traditional crafts than the other tribes, they used the highest number of hemiepiphytic species (9), followed by the Huitoto (8), Andoke (7), Piapoco and Yukuna (both 6 spp.) and the Piaroa (5 spp.). The Leticia region seemed to harbour more species of useful hemiepiphytes than the Vichada area. In accordance to Prance et al. (1987), the differences in fibre use between the three study sites reflects both the plant diversity within the surrounding forests and intercultural differences between the indigenous groups.

\section{Influence of the craft trade on indigenous livelihoods in the Vichada}

The colonization by landless farmers from the Andean foothills, the rise and fall of the rubber industry (18901920), the enforced conversion to Christianity and sed- 
entary lifestyles, and the integration in the market economy have all greatly influenced the traditional lifestyles of the Piaroa and Piapoco Indians. Recently, the activities of guerilla groups and coca farms have offered employment to young Piaroa men (Lobo-Guerrero et al. 2000). Several coca plots were present in the Cumaral Resguardo, and some of them had existed for as long as 10 years. We observed no coca plantations near the Piapoco communities in 1999 and no villagers were involved in the coca business. As opposed to the indigenous groups of the Caquetá and Amazonian forests, the Piapoco and the Piaroa have never used coca leaves as a traditional medicine or stimulant (Davis 1983).

In the last decade, Etnollano has carried out extensive surveys on community wellbeing and infant nutrition and health (Lobo-Guerrero et al. 2000). They discovered that in households of which the fathers had temporarily moved away from the community to work at coca plantations, children were suffering more from malnutrition and diseases than in households where the father stayed in the community and spend his time hunting, fishing and helping the mother to tend the family's agricultural plots. The labourers often spent their wages away from the community, leaving the children with a protein-poor diet and the mother with the heavy workload tending the garden alone (Herrera \& Lobo-Guerrero 1998). According to LoboGuerrero et al. (2000), the emerging coca business in the 1990s has caused social disruption and instability in the Cumaral community.

By means of their handicraft projects, Etnollano tries to combine the recovery of indigenous knowledge with the generation of alternative sources of income. They also aim to reinforce the social relations and the cultural identity of the Piaroa communities (Herrera \& Lobo-Guerrero 1998). Since they sell baskets in Bogotá for at least US\$ 25 per piece, the craft projects do offer an attractive alternative income to coca growing. Piaroa men now spend considerably more time with their families and combine aerial root harvesting and craftmaking with subsistence activities. Expectations that income generated by craft production would help to decrease child mortality and improve indigenous livelihoods seem to have become reality. The general health status of children from households that were involved in craft projects was much higher and malnutrion cases were less frequent than in families depending on coca growing activities (Lobo-Guerrero et al. 2000).

\section{Sustainability of craft fibre harvesting}

Etnollano advertises their craft projects as 'ecologically sustainable' (www.etnollano.org). Felling forest for coca plantations definitely clearly has a more destructive impact on the forest than harvesting hemiepiphytes, but it remains to be seen if the present levels of aerial root extraction in the Vichada can be considered sustainable. No environmental impact studies were done before the craft projects started. Although we did not perform a quantitative assessment of the hemiepiphyte populations, we did notice compelling indications of a decline in resources. Piaroa craft makers said much more roots are collected now than before. Hemiepiphytes were becoming scarce around the communities, and people had to walk further in the forest in order to collect their fibres. A similar situation was described by Piapoco harvesters selling roots to the furniture industry in Puerto Inírida.

NTFP extraction can only be considered as sustainable when populations do not become extinct as a result of exploitation, and when the productivity of the populations (in terms of availability of the extracted product) does not decline (Zuidema 2000). We therefore believe that present harvesting intensities are not sustainable. Our harvesting experiments indicated that harvesting more than $50 \%$ of the mature roots has a negative effect on the reproduction and survival of the hemiepiphytes. This was confirmed by similar experiments with $\mathrm{H}$. flexuosa in Guyana (Hoffman 1997) and Brazil (Plowden et al. 2003). Since the Piaroa have abandoned their traditional nomadic lifestyle and settled in permanent villages, there is a serious risk of overharvesting craft fibres. If the resources continue to dwindle and no sustainable management system is followed, the moment might come that root harvesting becomes too time-consuming and extractors might shift again to more favorable jobs, such as working on coca fields.

Several authors have warned against overharvesting of $H$. flexuosa by the furniture industry. Plowden et al. (2003) report that current harvesting practices in the eastern Brazilian Amazon have a deleterious effect on host plants. In Guyana, the results of uncontrolled extraction have led to the main furniture producer moving to another extraction site (Hall 2000). In Venezuela, the furniture industry caused a substantial decline in the production of $H$. spruceana roots in the late 1990s (Sanchez 1999). The same is happening with Thoracocarpus bissectus in Peru (Baluarte \& del Castillo 2001). While this over-harvesting of NTFPs is often associated with contemporary commercial exploitation (Pedersen \& Balslev 1992, Zuidema 2000), indigenous overharvesting of preferred species also occurred before the advent of Western civilization (Davis \& Yost 1983, Roth 1924).

\section{Does the craft trade preserve indigenous culture?}

Only village elders could tell the differences between the various hemiepiphytes. People below the age of 40 generally did not know the plants or their vernacular names. Most species had a specific name in the local indigenous language, while the Spanish language only provided the general name of bejuco or yare. Knowing local plant names in most cases also implies knowing their uses. Together with the erosion of indigenous languages, ethnobotanical knowledge is lost as well. In his research 


\section{Balcázar and van Andel - The Use of Hemiepiphytes as Craft Fibres by Indigenous Communities in the Colombian Amazon}

among the Venezuelan Piaroa, Zent (2001) discovered that the more formal education (in Spanish) people received, the less ethnobotanical knowledge they retained. The recuperation of indigenous names and cultural reinforcement is fundamental for the reconstruction of traditional knowledge and reflection about territory and its care (van der Hammen 1992).

Can the basketry trade lead to the preservation of indigenous culture? The first attempt by Etnollano to sell traditional Piaroa crafts was not successful. They now weave new, non-indigenous designs that meet the demand of the customers in Bogotá. The craft project might have helped the Piaroa to recapture their knowledge of hemiepiphytes, but did not encourage them to conserve their typical Piaroa artefacts. If their goal is to preserve indigenous culture, Etnollano should put more effort in marketing original designs and objects. Venezuelan Piaroa involved in commercial fibre extraction and furniture production made and used less traditional crafts than those with less contact with the market economy (Zent 2001). On the other hand, just four years after the Etnollano health program started, traditional healers emerged again from the indigenous communities in the Brazo Amanavén (they had never really been lost) and a new valuation of indigenous knowledge and tradition evolved (Lobo-Guerrero et al. 2000).

\section{Conclusions and recommendations}

The basketry project in the Vichada is a clear example of how commercial NTFP extraction can improve local people's livelihood and even contribute (to a certain extent) to the conservation of indigenous culture. Craft production fits in the traditional indigenous lifestyle and combines easily with subsistence activities that are essential to the community's wellbeing. Selling crafts can help indigenous people to become less dependent on coca plantations and guerilla warfare for their income. Such craft programmes, however, should make use of sustainable fibre extraction methods.

When native communities are stimulated to settle in permanent villages, the use of local resources is intensified and their habitat degraded over time (Santos et al. 1997). The fact that hemiepiphytes need living trees as a host and suitable roots are predominantly found in primary forest will add extra value to standing forest. The maintenance of this forest is thus essential for the future supply of the product. If prices are high enough, commercial root harvesting can prevent people to a certain extent from timber harvesting or other destructive land uses. Given their potential for forest conservation, their economic importance and possibilities for sustainable harvest, there is an urgent need for developing adequate management plans for these species.
Information on the demography of commercial species and the impact of their exploitation is essential to assess the impact on future resource availability (Hall \& Bawa 1993). There is a need for further research on the dynamics of individuals and populations and the consequences of aerial root removal for demographic rates and life history characteristics. Only with this knowledge can we determine whether current (or alternative) harvest regimes are sustainable and how much time populations need to regain pre-harvest size and structure (Balcázar 2004, Bernal 1998, Ticktin et al. 2002, Zuidema 2000).

Once sustainable extraction levels are calculated and tested, management plans should be set up, in which community members are actively involved and which fit within the plans for natural resource management of the indigenous resguardos (van der Hammen 2003). The Caquetá and Amacayacu seem to be promising areas for similar "Etnollano type" projects, as indigenous weaving skills still exist, communities are interested in craft marketing (Rodriguez 2003) and regular (cargo) flights are available for craft transport to the capital. There are no restrictions to resource access, since indigenous peoples have the exclusive right to harvest NTFPs in their resguardos (van der Hammen 2003). Stimulating the marketing of basketry could serve as an economic incentive to indigenous people and make them more independent from the guerilla and drug trade.

\section{Acknowledgements}

This research was financed by the Dutch embassy in Bogotá, the Tropenbos-Colombia programme and the Fundación Etnollano. We acknowledge $\mathrm{C}$. Rodriguez and $\mathrm{A}$. Jaramillo for their logistic support and collaboration. We thank C. van der Hammen for her comments and assistance during the fieldwork and $\mathrm{J}$. Wolf for his comments and corrections. Quiero agradecer especialmente a mi compañera y amiga L. Sastoque por su invaluable trabajo en campo, su amistad y compañía. We are also very greateful to B. Castro, A. Suárez and C. Fariñame (Araracuara), the families Andoke (Aduche), Yukuna (Araracuara) and Matapí (Caquetá) for sharing their experience. We also thank the personnel of the Parque Nacional Natural Amacayacu and the Mocagua, Macedonia and el Vergel communities (Tikuna) for their assistance in the field. We thank the families Medina, Gaitán, García and Pérez (Yuri), Fuentes and Navarro (Cumaral) for their assistance in the field. We appreciated the valuable help from J. de Greiff during some difficult days in the Selva de Matavén. We are also grateful to José Luis Fernández (COL), and Dairón Cárdenas (SINCHI). 


\section{Literature Cited}

Acero, L.E. 1979. Principales plantas útiles de la Amazonia Colombiana. Proyecto Radargramétrico del Amazonas, Bogotá.

Andel, T.R. van. 2000. Non-Timber forest products of North-West District of Guyana. Tropenbos Guyana Series $8 \mathrm{~A}$ and $8 \mathrm{~B}$, Utrecht.

Andel, T.R. van, A. MacKinven \& O.S. Bánki. 2003. Commercial Non-Timber Forest Products of the Guina Shield. NC-IUCN, Amsterdam.

Angrist, J. \& A.D. Kugler. 2005. Rural Windfall or a New Resource Curse? Coca, Income, and Civil Conflict in Colombia. National Bureau of Economic Research Working Paper. W11219. Cambridge.

Balcázar, M.P. \& L. Sastoque. 1999. Bejucos y Cultura material en el Medio Río Caquetá. Comunidades indígenas del Medio Río Caquetá y Fundación Tropenbos-Colombia, Bogotá.

Balcázar, M.P. 2000. Especies de bejucos empleadas en la fabricación de artefactos de la cultura material, por las comunidades indígenas Piapoco y Piaroa del Brazo Amanavén, Vichada, Colombia. Fundación Etnollano, Bogotá.

Balcázar, M.P. 2002. Bejucos útiles en el área del Trapecio Amazónico. Parque Nacional Amacayacu and Tropenbos-Colombia, Bogotá

Balcázar M.P. 2004. Demography of Attalea butyracea in the Bolivian Amazon. MSc thesis, Utrecht University.

Baluarte, J. \& D. del Castillo Torres. 2001. Tamshi: otro producto no maderable de los bosques amazónicos con importancia económica. Folia Amazónica 12:155-160.

Bennett, B. 1992. Uses of Epiphytes, lianas, and parasites by the Shuar people of Amazonian Ecuador. Selbyana 13:99-114.

Benzing, D.H. 1990. Vascular epiphytes: general biology and related biota. Cambridge University Press, Cambridge.

Bernal, R.G. 1992. Colombian palm products. Pp 158-172 in Sustainable harvest and marketing of rain forest products. Edited by M. Plotkin \& L. Famolare. Island Press, Washington, DC.

Bernal, R.G. 1998. Demography of the vegetable ivory palm Phytelephas seemannii in Colombia, and the impact of seed harvesting. Journal of Applied Ecology 35:64-74.
Boot, R.G.A. 1997. Extraction of non timber forest products from tropical rain forests. Does diversity come at a price? Netherlands Journal of Agricultural Science 45:39450.

Cárdenas, D. \& R. Lopez. 2000. Plantas útiles de la Amazonía Colombiana, Departamento del Amazonas. Instituto Amazónico de Investigaciones Científicas (SINCHI), Bogotá.

Clark, L.E. \& T.C.H. Sunderland. 2004. The Key Non-Timber Forest Products of Central Africa: State of the Knowledge. USAID Technical Paper 122. Washington, DC.

Clay, J. 1992. Some general priciples and strategies for developing markets in North America and Europe for Nontimber forest products. Pp 302-309 in Sustainable harvest and marketing of rain forest products. Edited by M. Plotkin \& L. Famolare. Island Press, Washington, DC.

Croat, T. 1992. Species diversity of Araceae in Colombia: a preliminary survey. Annals of Misouri Botanical Garden 79:17-28.

Davies, G. 2002. Bushmeat and International Development. Conservation Biology 16:587-589.

Davis, E.W. 1983. The ethnobotany of chamairo Mussatia hyacinthina. Journal of Ethnopharmacology 9:225-236

Davis, E.W. \& J.A. Yost. 1983. The Ethnobotany of the Waorani of eastern Ecuador. Harvard University Botanical Museum Leaflets 29:159-217.

Dirección Nacional de Planeación (DNP). 1991. Política para el desarrollo y la conservación de la Amazonia. Colombia Amazónica 5:11-44.

Dirección Nacional de Planeación (DNP). 1999. Participación de los resguardos indígenas en los ingresos corrientes de la nación reducción vigencia. Bogotá.

Dirección Nacional de Planeación (DNP). 2002. Los pueblos indígenas de Colombia en el umbral del nuevo milenio. Bogotá.

Duivenvoorden, J. F. \& J. M. Lips. 1993. Ecología del Paisaje del Medio Caquetá. Estudios en la Amazonia Colombiana 3A/B, Bogotá.

Duivenvoorden, J.F., H. Balslev, J. Cavelier, C. Grandez, H. Tuomisto \& R. Valencia. 2001. Editors of Evaluación de recursos vegetales no maderables en la Amazonía noroccidental. University of Amsterdam, Amsterdam.

Duque, A., M. Sánchez, J. Cavelier \& J.F. Duivenvoorden. 2002. Different floristic patterns of woody understorey and 


\section{Balcázar and van Andel - The Use of Hemiepiphytes as Craft Fibres by Indigenous Communities in the Colombian Amazon}

canopy plants in Colombian Amazonia. Journal of Tropical Ecology 18:499-525.

Duque, A. 2004. Plant diversity scaled by growth forms along spatial and environmental gradients. Ph.D. thesis University of Amsterdam, Amsterdam.

El Tiempo. 2003. Olvidados entre los Olvidados. El Tiempo 8 August 2003, Bogotá.

Garzón, N. \& V. Macuritofe. 1992. La noche, las plantas y sus dueños: aproximación al conocimiento de una cultura Amazónica. Corporación Colombiana para la Amazonia, Bogotá.

Gentry, A.H. 1992. New non-timber forest products from western South America. Pp 132 in Sustainable harvest and marketing of rain forest products. Edited by M. Plotkin \& L. Famolare. Island Press, Washington, DC.

Glenboski, L.L. 1983. The ethnobotany of Tukuna Indians, Amazonas, Colombia. Biblioteca José Jeronimo Triana 4. Universidad Nacional de Colombia, Bogotá.

González, L. 1989. Tecnología, ecología y sociedad una aproximación etnográfica a los Piapocos del bajo Guaviare. Universidad Nacional de Colombia, Bogotá.

Hall, L. 2000. Effects of NTFP harvesting on populations of Manilkara bidentata and Heteropsis flexuosa in central Guyana. University of West England, Bristol.

Hall, P. \& K.S. Bawa. 1993. Methods to assess the impact of extraction of non-timber tropical forest products on plant populations. Economic Botany 47:234-247.

Hammen, M.C. van der. 1992. El manejo del mundo: naturaleza y sociedad entre los Yukuna de la Amazonia Colombiana. Estudios en la Amazonia Colombiana IV, Bogotá.

Hammen, M.C. van der. 2003. The Indigenous Resguardos of Colombia: their contribution to conservation and sustainable forest use. NC-IUCN, Amsterdam.

Herrera, X. \& M. Lobo-Guerrero. 1998. Promoción de la salud desde la comunidad. Fundación Etnollano. Tercer Mundo Editores, Bogotá.

Hoffman, B. 1997. The biology and use of nibbi Heteropsis flexuosa (Araceae): the source of an aerial root fibre product in Guyana. M.S. thesis, Florida International University, Miami.

IGAC (Instituto Geografico Augustin Codazzi). 1970. Atlas Basico de Colombia. Edición Patrocinada por el Banco de la República, Bogotá.
Knap-Vispo, C., B. Hoffman, T. Moermond \& C. Vispo. 2003. Ecological observations on Heteropsis spp. (Araceae) in Southern Venezuela. Economic Botany 57:345353.

Kress, W.J. 1986. The systematic distribution of vascular epiphytes: an update. Selbyana 9:2-22.

La Rotta, C. 1982. Observaciones etnobotánicas de la comunidad Andoque de la Amazonia colombiana. Colombia Amazónica 1:54-67.

La Rotta, C., P. Miraña, M. Miraña, B. Miraña, M. Miraña \& N. Yukuna. 1987. Especies utilizadas por la comunidad Miraña Amazonas Colombia: estudio etnobotánico. WWF and José Celestino Mutis Foundation, Bogotá.

Leimbeck, R.M. \& H. Balslev. 2001. Species richness and abundance of epiphytic Araceae on adjacent floodplain and upland forest in Amazonian Ecuador. Biodiversity and Conservation 10:1579-1593.

Lobo-Guerrero, M., X. Herrea, J. de Greiff \& A. Luque. 2000. Editors of Matavén, Selva corazón de la salud. Panamericana Formas e Impresos, Bogotá.

Mayo, S.J., J. Bogner, P.C. Boyce, J.C. French \& R. Hegnauer. 1997. The genera of Araceae. Royal Botanical Gardens, Kew.

Moffett, M. W. 2000. What's "up"? A critical look at the basic terms of canopy biology. Biotropica 32:569-596.

Nepstad, D.C. \& S. Schartzman. 1992. Non-timber product extraction from tropical forest: evaluation of a conservation and development strategy. Advances in Economic Botany 9:7-12.

Newton, A.C., Marshall, E., Schreckenberg, K. \& D. Golicher. 2002. Commercialisation of non-timber forest products: analysis of the factors influencing success. International Forestry Review 5:128-137

Ortiz, R. 1994. Uso, conocimiento y manejo de algunos recursos naturales en el mundo Yukuna. Abya Yala, Quito.

Paredes, M., L.E. Alvarado, H.H. Bernal \& A.J. Chamorro. 2003. Colombia's war against drugs. Actions and results 1999-2000. National Anti-Narcotics Agency, Bogotá.

Paz y Miño, C.G., H. Balslev \& R. Valencia. 1995. Useful lianas of the Siona-Secoya Indians from Amazonian Ecuador. Economic Botany 49:269-275.

Pedersen, H. \& H. Balslev. 1992. Economic Botany of Ecuadorean palms. Pp 173-191 in Sustainable harvest and 
marketing of rain forest products. Edited by M. Plotkin \& L. Famolare. Island Press, Washington DC.

Peters, C.M. 1996. Observation on the sustainable exploitation of non-timber tropical forest products: an ecologist's perspective. Pp 19-39 in Current issues in non-timber forest products research. Edited by M. Ruiz-Peres \& J.E.M. Arnold, CIFOR, Bogor.

Plotkin, M. and L. Famolare. 1992. Editors of Sustainable harvest and marketing of rain forest products. Island Press, Washington, DC.

Plowden C., C. Uhl \& F.A. Oliveira. 2003. The ecology and harvest potential of titica vine roots (Heteropsis flexuosa: Araceae) in the eastern Brazilian Amazon. Forest Ecology and Management 182:59-73.

Prance, G.T., Ballee, W., B.M. Boom \& R.L. Carneiro. 1987. Quantitative Ethnobotany and the Case for Conservation in Amazonia. Conservation Biology 1:296-310.

Putz, F.E. \& N.M. Holbrook. 1986. Notes on the natural history of hemiepiphytes. Selbyana 9:61-69.

Reichel, E. 1987. Los Tukuna. Pp 235-274 in Colombia Amazónica: etnografía de los indígenas contemporáneos. Edited by Universidad Nacional de Colombia, Bogotá.

Rodríguez, C.A. 1999. Arponeros de la trampa del sol: sustentabilidad de la pesca comercial en el medio Río Caquetá. Tropenbos-Colombia Series 18, Wageningen.

Rodríguez, C.A. 2003. Proyectos plata-proyectos pensamiento. Pp 3-17 in Alternativas productivas en la Amazonia colombiana: Enfoques y procesos desde lo local. Edited by M.V. Rivera Páez, COAMA, Bogota.

Romero, M., S. Sua N. Rodríguez, G. Rudas \& D. Armenteras. 2004. Sistema de indicadores de seguimiento de la política de biodiversidad en la Amazonia Colombiana: aspectos metodológicos y resultados. Instituto de Investigación de Recursos Biológicos Alexander von Humboldt, Bogotá.

Roth, W.E. 1924. An inquiry into the arts, crafts and customs of the Guiana Indians. Smithsonian Institution Bureau of American Ethnology, Annual Report 38. Washington DC.

Ruiz-Perez, M. \& J.E.M. Arnold. 1996. Current issues in non-timber forest products research. CIFOR, Bogor, Indonesia.

Sánchez, I. 1999. Algunos aspectos ecológicos del mamure (Heteropsis spruceana Schott) de interés potencial para su domesticación y manejo. M.Sc. thesis Universidad Central de Venezuela, Caracas.
Sánchez, M. 1997. Catálogo preliminar comentado de la flora del Medio Caquetá. Estudios en la Amazonia Colombiana XII, Bogotá.

Sánchez, M. 2005. Use of tropical rain forest biodiversity by indigenous communities in northwestern Amazonia. Ph.D. thesis, University of Amsterdam.

Santos R., N. Flowers, C. Coimbra \& S. Gugelmin. 1997. Tapirs, tractors and tapes: the changing economy and ecology of the Xavante Indians of Central Brazil. Human Ecology 25:545-566.

Schultes, R.E \& R.F. Raffauf. 1990. The healing forest. Medicinal and Toxic Plants of the Northwest Amazonia. Dioscorides Press, Portland,.

Shanley, P., L. Luz, \& I.R. Swingland. 2002a. The faint promise of a distant market: a survey of Belém's trade in non-timber forest products. Biodiversity and Conservation $11: 615-636$.

Shanley, P., Pierce, A.R., Laird, S.A. \& A. Guillen. 2002b. Editors of Tapping the Green Market: Certification and Management of Non-Timber Forest Products. Earthscan Publications, London.

Ticktin, T., P. Nantel, F. Ramírez \& T. Johns. 2002. Effects of variation on harvest limits for non-timber forest species in Mexico. Conservation Biology 16:691-705.

Ticktin, T. 2004. The ecological implications of harvesting non-timber forest products. Journal of Applied Ecology 41:11-21.

Villalón, C. 2004. Cocaine country. National Geographic Magazine July 2004:34-55.

Villegas, C., A. Rudas, \& A. Prieto. 2004. Estudio florístico de dos hectáreas de bosque de tierra firme en la Amazonia colombiana (Parque Nacional Natural Amacayacu). Pp 469 in Libro de Resúmenes VIII Congreso Latinoamericano y II Congreso Colombiano de Botánica. Edited by J.O. Rangel, J. Aguirre \& M.G. Andrade. Universidad Nacional de Colombia, Bogotá.

Wallace, R. \& E. Ferreira. 2000. Extractive exploitation of cipó titica (Heteropsis flexuosa (H.B.K.) Bunt., Araceae) in Acre: management and market potential. The New York Botanical Garden, Bronx NY.

Whitehead B.W. \& R. Godoy. 1991. The extraction of rattan-like lianas in the New World: a possible prototype for sustainable forest management. Agroforestry Systems 16:247-255.

Zent, S. 2001. Acculturation and ethnobotanical knowledge loss among the Piaroa of Venezuela. Pp 190-211 in 


\section{Balcázar and van Andel - The Use of Hemiepiphytes as Craft Fibres by Indigenous Communities in the Colombian Amazon}

On Biocultural Diversity: Linking Language, Knowledge, and the Environment. Edited by L. Maffi. Smithsonian Institution Press, Washington, DC.

Zuidema, P.A. 2000. Demography of exploited tree species in the Bolivian Amazon. Ph.D. thesis Utrecht University, Utrecht. 
Appendix 1. Hemi-epiphytic species used for craft making in the Colombian Amazon.

\begin{tabular}{|c|c|c|c|c|c|c|c|}
\hline \multirow{2}{*}{$\begin{array}{l}\text { Species and } \\
\text { collection } \\
\text { numbers }\end{array}$} & \multicolumn{6}{|c|}{ Ethnic groups and vernacular names } & \multirow[t]{2}{*}{ Crafts (indigenous terms) } \\
\hline & Uitoto & Andoke & Yukuna & Piapoco & Piaroa & Tikuna & \\
\hline \multirow{3}{*}{$\begin{array}{l}\text { Heteropsis sp. } \\
\text { MPB } 648648 \\
1163,1164 \\
1174,1221\end{array}$} & kirio' 1 & & & & & & $\begin{array}{l}\text { Creels (to'naaru rigoru) } \\
\text { Brooms (raa'taba) } \\
\text { Baskets (kirigai and kirinikoi) }\end{array}$ \\
\hline & & & & $\begin{array}{l}\text { mamiri } \\
\text { manuiri } \\
\text { masaca- } \\
\text { niri }\end{array}$ & & & $\begin{array}{l}\text { Binding material for houses } \\
\text { Baskets (mapiri, turca, cholota, dui- } \\
\text { ri ibana), brooms (tononuzi), fish trap } \\
\text { (wauma, caculi, upisi), } \\
\text { mammal trap (chawi), Catumare carrying } \\
\text { basket, raw material for furniture industry }\end{array}$ \\
\hline & & & & & $\begin{array}{l}\text { dauwiyä } \\
\text { reyottü } \\
\text { huipo }\end{array}$ & & $\begin{array}{l}\text { Binding material for houses } \\
\text { Baskets (dejäkä, dejä or mapire, wiräyu), } \\
\text { container for blow pipe darts (quïtäna), } \\
\text { brooms (jua, attähuächu), Yuruhuäbä } \\
\text { Hot pot holder (Sämuracä) } \\
\text { Catumare carrying basket }\end{array}$ \\
\hline \multirow{6}{*}{$\begin{array}{l}\text { Heteropsis } \\
\text { flexuosa } \\
\text { (H.B.K.) G.S. } \\
\text { Bunting } \\
\text { MPB 561, } \\
579,647,651 \text {, } \\
653,673,681 \text {, } \\
1176,1221, \\
1403,1404\end{array}$} & irio $^{1}$ & & & & & & Traps (naacopo, iredai, naacurada) \\
\hline & & $\begin{array}{l}\text { i'płkodt- } \\
\text { knt'1 }\end{array}$ & & & & & 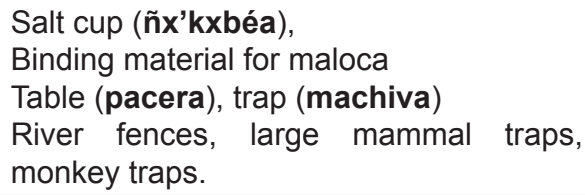 \\
\hline & & & yuriyú ${ }^{1}$ & & & & $\begin{array}{l}\text { Broom (chio'pá), spell cups } \\
\text { (umichiripuku), fish trap (upichí), fence } \\
\text { for the maloca, Border of the balay sieve }\end{array}$ \\
\hline & & & & $\begin{array}{l}\text { cawamai } \\
\text { iyapicoa }^{2}\end{array}$ & & & $\begin{array}{l}\text { Binding material for houses } \\
\text { Basket (mapire) }\end{array}$ \\
\hline & & & & & $\begin{array}{l}\text { acui } \\
\text { huäsä } \\
\text { huipo }^{2}\end{array}$ & & $\begin{array}{l}\text { Binding material for walls, hot pot holder } \\
\text { (Sämuracä), fish basket (cahuítä), fish } \\
\text { trap (huiyu, huibä), trap (cäcuri) }\end{array}$ \\
\hline & & & & & & tüu ${ }^{3}$ & $\begin{array}{l}\text { Binding material for houses } \\
\text { Baskets, brooms, traps }\end{array}$ \\
\hline \multirow{2}{*}{$\begin{array}{l}\text { Heteropsis } \\
\text { linearis } \\
\text { A.C. Sm. } \\
\text { MPB } 674 \\
1494,1495\end{array}$} & & i'tetanó $^{1}$ & & & & & Basket (ojón or ө’efeí), Trap (machiva) \\
\hline & & & & & & omachi & $\begin{array}{l}\text { Basket (panero), brooms } \\
\text { Binding material for houses }\end{array}$ \\
\hline \multirow{3}{*}{$\begin{array}{l}\text { Heteropsis } \\
\text { oblongifolia } \\
\text { Kunth } \\
\text { MPB } 671\end{array}$} & kirio' 1 & & & & & & $\begin{array}{l}\text { Creel (to'naaru } \begin{array}{c}\text { figeru), brooms } \\
\text { (raa'taba), baskets (kirigaí \& kirintkoi) }\end{array} \\
\end{array}$ \\
\hline & & $\begin{array}{l}\text { p'amita- } \\
\text { nó }{ }^{1}\end{array}$ & & & & & Creel (yióe and pa'mí), baskets \\
\hline & & & Yurape $^{1}$ & & & & $\begin{array}{l}\text { Basket (pajluaja ñe'ejeri and iyamá } \\
\text { ñe'ejeri) }\end{array}$ \\
\hline
\end{tabular}




\section{Balcázar and van Andel - The Use of Hemiepiphytes as Craft Fibres by Indigenous Communities in the Colombian Amazon}

\begin{tabular}{|c|c|c|c|c|c|c|c|}
\hline \multirow{2}{*}{$\begin{array}{l}\text { Species and } \\
\text { collection } \\
\text { numbers }\end{array}$} & \multicolumn{6}{|c|}{ Ethnic groups and vernacular names } & \multirow[t]{2}{*}{ Crafts (indigenous terms) } \\
\hline & Uitoto & Andoke & Yukuna & Piapoco & Piaroa & Tikuna & \\
\hline \multirow[t]{2}{*}{$\begin{array}{l}\text { Heteropsis } \\
\text { spruceana } \\
\text { Schott } \\
\text { var. robusta } \\
\text { Bunting } \\
\text { MPB } 1160, \\
1165,1210\end{array}$} & & & & $\begin{array}{l}\text { mamiri } \\
\text { manuiri } \\
\text { masaca- } \\
\text { niri }^{2}\end{array}$ & & & $\begin{array}{l}\text { Binding material for houses, Baskets } \\
\text { (mapiri, turca, cholota, duiri ibana), } \\
\text { brooms (tononuzi), fish trap (wauma, } \\
\text { caculi, upisi), mammal trap (chawi), } \\
\text { Catumare carrying basket } \\
\text { Raw material for furniture }\end{array}$ \\
\hline & & & & & $\begin{array}{l}\text { dauwiyä } \\
\text { reyottü } \\
\text { huipo }^{2}\end{array}$ & & $\begin{array}{l}\text { Binding material for houses, Baskets } \\
\text { (dejäkä, dejä o mapire, wiräyu), } \\
\text { container for blow pipe darts (quïtäna), } \\
\text { brooms (jua, attähuächu), Yuruhuäbä, } \\
\text { hot pot holder (Sämuracä), Catumare } \\
\text { carrying basket, Raw material furniture } \\
\text { industry }\end{array}$ \\
\hline \multirow{2}{*}{$\begin{array}{l}\text { Heteropsis } \\
\text { spruceana } \\
\text { Schott } \\
\text { var. spruceana } \\
\text { MPB } 1259 \\
\text { A, } 1279\end{array}$} & nanio ${ }^{1}$ & & & & & & Basket 'canasta ojón' (gebogaí) \\
\hline & & & & $\begin{array}{l}\text { mamiri } \\
\text { puberi }^{2}\end{array}$ & & & $\begin{array}{l}\text { Trap (chawi), fish traps (upisi, wauma, } \\
\text { caculi) }\end{array}$ \\
\hline \multirow{4}{*}{$\begin{array}{l}\text { Philodendron } \\
\text { goeldii G.M. } \\
\text { Barroso } \\
\text { MPB 592, } \\
1410,1411\end{array}$} & meemeo & & & & & & Binding material for houses \\
\hline & & kodie & & & & & $\begin{array}{l}\text { Binding material for houses } \\
\text { Border of the balay sieve }\end{array}$ \\
\hline & & & kawiri & & & & Binding material for houses \\
\hline & & & & & & womé & Brooms, binding material for houses \\
\hline \multirow{6}{*}{$\begin{array}{l}\text { Philodendron } \\
\text { solimoesense } \\
\text { A.C. Sm. }\end{array}$} & ñodokio & & & & & & Binding material for houses \\
\hline & & foéi & & & & & $\begin{array}{l}\text { Binding material for houses } \\
\text { ('cumbrera') }\end{array}$ \\
\hline & & & & & & & Binding material for houses \\
\hline & & & & $\begin{array}{l}\text { abeya } \\
\text { pirawa }\end{array}$ & & & $\begin{array}{l}\text { Binding material for houses } \\
\text { Baskets (duiri ibana, turca) }\end{array}$ \\
\hline & & & & & $\begin{array}{l}\text { sibari } \\
\text { huipo }\end{array}$ & & $\begin{array}{l}\text { Binding material for walls } \\
\text { Baskets (dejä or mapire, wirayü), part of } \\
\text { the sieve holder (ruttubä or cernidor) }\end{array}$ \\
\hline & & & & & & $\begin{array}{l}\text { womé } \\
\text { tuuaü }\end{array}$ & Binding material for houses, brooms \\
\hline $\begin{array}{l}\text { Philodendron } \\
\text { wurdackii } \\
\text { G.S. Bunting } \\
\text { MPB } 670\end{array}$ & & $\begin{array}{l}\text { hi'katata- } \\
\text { nó }\end{array}$ & & & & & Provisional binding material \\
\hline $\begin{array}{l}\text { Philodendron } \\
\text { sp. MPB } 1401 \\
\text { MPB 1401, } \\
1419 .\end{array}$ & & & & & & $\begin{array}{l}\text { womé } \\
\text { bainü- } \\
\text { takú }\end{array}$ & $\begin{array}{l}\text { Binding material for houses } \\
\text { Brooms }\end{array}$ \\
\hline $\begin{array}{l}\text { Philodendron } \\
\text { sp. MPB } 1423\end{array}$ & & & & & & $\begin{array}{l}\text { enepa- } \\
\text { main }\end{array}$ & $\begin{array}{l}\text { Binding material for houses } \\
\text { Brooms }\end{array}$ \\
\hline $\begin{array}{l}\text { Asplundia sp. } \\
\text { MPB } 1405 \\
1416\end{array}$ & & & & & & chopure & $\begin{array}{l}\text { Binding material for houses } \\
\text { Baskets, brooms }\end{array}$ \\
\hline
\end{tabular}




\begin{tabular}{|c|c|c|c|c|c|c|c|}
\hline \multirow{2}{*}{$\begin{array}{l}\text { Species and } \\
\text { collection } \\
\text { numbers }\end{array}$} & \multicolumn{6}{|c|}{ Ethnic groups and vernacular names } & \multirow[t]{2}{*}{ Crafts (indigenous terms) } \\
\hline & Uitoto & Andoke & Yukuna & Piapoco & Piaroa & Tikuna & \\
\hline \multirow{3}{*}{$\begin{array}{l}\text { Evodianthus } \\
\text { funifer (Poit.) } \\
\text { Lindm. } \\
\text { MPB 581, } \\
654,1406, \\
1413,1475\end{array}$} & guio & & & & & & $\begin{array}{l}\text { Basket (iíbigaí, ba'kigaí, ne'nigai) } \\
\text { Border of the balay sieve }\end{array}$ \\
\hline & & & kapatú & & & & $\begin{array}{l}\text { Baskets (pajluaja ñe'ejeri and iyamá } \\
\text { ñe'ejeri) }\end{array}$ \\
\hline & & & & & & chopure & $\begin{array}{l}\text { Binding material for houses } \\
\text { Baskets, Brooms }\end{array}$ \\
\hline $\begin{array}{l}\text { Sphaeradenia } \\
\text { sp. MPB } 676\end{array}$ & fi'eié & & & & & & $\begin{array}{l}\text { Baskets (trihennde'o, canasta ojón or } \\
\text { e'efeí) }\end{array}$ \\
\hline \multirow{5}{*}{$\begin{array}{l}\text { Thoracocarpus } \\
\text { bissectus } \\
\text { (Vell.) Harling } \\
\text { MPB 594, } \\
655,1218, \\
1269,1407, \\
1409,1417, \\
1421,1442\end{array}$} & guio & & & & & & $\begin{array}{l}\text { Basket (iíbigaí, ba'kigaí, ne'nígaí) } \\
\text { Border of the balay sieve }\end{array}$ \\
\hline & & & marapé & & & & $\begin{array}{l}\text { Baskets (pajluaja ñe'ejeri and iyamá } \\
\text { ñe'ejeri) }\end{array}$ \\
\hline & & & & $\begin{array}{l}\text { iwi } \\
\text { mamiri }\end{array}$ & & & $\begin{array}{l}\text { Binding material for houses } \\
\text { Basket (mapiri) }\end{array}$ \\
\hline & & & & & $\begin{array}{l}\text { puori } \\
\text { huipo }\end{array}$ & & $\begin{array}{l}\text { Binding material for houses } \\
\text { Baskets (dejä mapire, wirayü, dejäkä), } \\
\text { base of the sieve holder or (ruttubä), } \\
\text { cassava bread holder (guapa) }\end{array}$ \\
\hline & & & & & & $\begin{array}{l}\text { chopure } \\
\text { propio }^{3}\end{array}$ & $\begin{array}{l}\text { Binding material for houses } \\
\text { Baskets, brooms }\end{array}$ \\
\hline
\end{tabular}

1. Named Yare in Spanish.

2. Named Mimbre in Spanish.

3. Named Tamishi in Spanish. 